\title{
Research on the Construction of the Curriculum System of Tourism Management under OBE Education Mode
}

\author{
Jianhua Wang \\ Jiangsu Vocational College of Business \\ Jiangsu, China
}

\begin{abstract}
China has become a formal member of the Washington Agreement. Now more and more colleges and universities recognize and practice the "student-centered" and "result-oriented education". The curriculum system of OBE mode specialty is based on the market demand, industry standards and ability training to design the expected learning output. Students are placed at the center to construct the curriculum system of tourism management specialty in higher vocational colleges. Starting with the training objectives of tourism management professionals, this paper dissects the teaching requirements and indicators in the formulation of the training plan, analyses the corresponding courses, and builds a curriculum system for the training of tourism management professionals in higher vocational colleges.
\end{abstract}

Keywords-OBE; training program; curriculum system

\section{INTRODUCTION}

OBE (Outcomes-based Education) is an educational model based on learning output. In the education system of OBE mode, firstly, we must clearly determine the ability and level that students should achieve when they graduate. Secondly, we should find a scientific curriculum system to ensure that students can achieve these expected goals. Student output promotes the operation of the education system. Student output is the driving force driving the operation of the education system, and the goal of teaching implementation is the final learning achievement of students. [1]

The concept of OBE has been proposed by American scholar Spady in 1981. Researchers believe that OBE is the transformation of educational mode. American scholar Spandy W. G believes that what students learn and whether they succeed is far more important than how and when they learn. The objective of OBE education mode is to make all students succeed through education. Educational structure and curriculum are regarded as methods rather than purposes. If they fail to contribute to the development of students' specific abilities, they will be rebuilt.

Some researchers believe that $\mathrm{OBE}$ is an educational process of learning output. For example, Tucker S. E. thinks that OBE is a structure and system that learning output drives the whole curriculum activities and students' learning output evaluation. [2]
Some researchers have carried out research on the application of OBE. For example, the Northern Alberta Institute of Technology (NAIT) in Canada introduced the concept of OBE into the process of professional design and curriculum development, which includes four steps: professional planning, teaching plan, outline curriculum and teaching plan design.

In August 2013, China became the 21st member of the Washington Agreement. This means that we will train engineers and technicians in accordance with international standards. The theory and application of OBE have attracted much attention.

II. RESEARCH ON THE CONSTRUCTION OF THE COURSE SYSTEM OF TOURISM MANAGEMENT MAJOR IN HIGHER VOCATIONAL COLLEGES UNDER THE OBE EDUCATION MODEL

\section{A. Research value}

Vocational education should be more targeted and practical. We should make it clear what learning outcomes we want our students to achieve. How should we design the curriculum system and content scientifically to effectively help students achieve these learning outcomes? The construction of curriculum system in a professional training program should not only focus on the cultivation of basic practical ability and social ability, but also on the training of practical skills. The application of OBE teaching theory shouldn't emphasize theory. Through comparative study, social investigation and practical exploration, we should deeply study the characteristics of students in higher vocational, the requirements of the tourism industry and the needs of relevant post competence. Only in this way can we construct a reasonable, scientific and operable curriculum system and achieve the goal of training talents for tourism management major in higher vocational colleges.

\section{B. Research contents and key points}

Under the OBE education mode, the students who major in tourism management in higher vocational colleges should achieve learning results.

We should determine the expected learning results of tourism management major in higher vocational colleges according to the market demand, industry standards, and 
parents' and students' expectations. Learning outcomes should fully take into account the requirements and expectations of various educational stakeholders.

The curriculum system and content support the tourism management specialty in higher vocational education under OBE mode.

Student's learning achievement is the embodiment of ability. The ability is mainly realized through the teaching of courses. There is a corresponding relationship between the competency structure and curriculum structure. Every kind of ability in the competency structure is supported by a clear curriculum. We should take the learning achievement as the center to construct the curriculum system and content support matrix of tourism management specialty in higher vocational colleges.

The organization and implementation of tourism management teaching is important in higher vocational colleges under the OBE education mode.

We should pay attention to each person's talent goal, foundation and learning environment, formulate different teaching methods and organize their implementation. In the process of teaching, we should merely emphasize what students have learned than what teachers have taught. We should focus on the output rather than the input of the teaching process.

Examination of learning achievement of students that major in tourism management in higher vocational education under OBE mode requires our attention.

We should adopt diversified evaluation criteria. We can make different grades according to the different requirements of different students. Through targeted evaluation, we can further grasp the students' learning status, improve the curriculum system and content support matrix structure of tourism management specialty, and further optimize the personnel training program.

\section{USING OBE IDEA TO IMPROVE THE TRAINING OF TOURISM MANAGEMENT PROFESSIONALS IN HIGHER VOCATIONAL COLLEGES}

A. Based on OBE theory, the design idea of our training program for tourism management professionals is shown in Fig. 1.

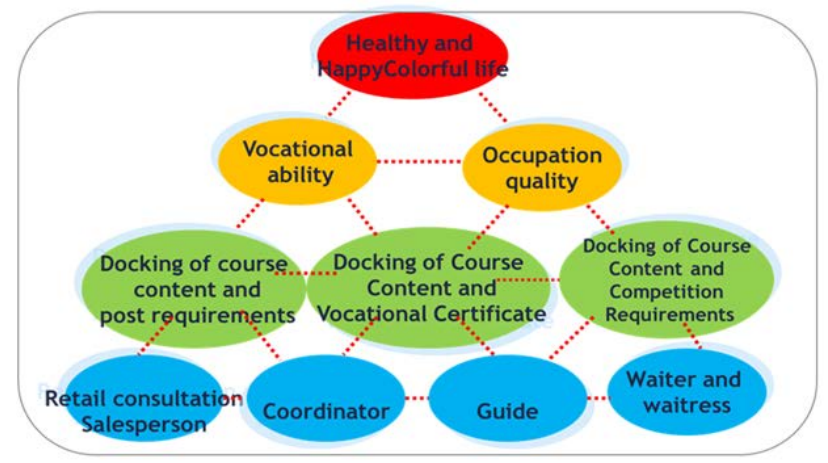

Fig. 1 Guiding ideas of professional construction
The main jobs for graduates of tourism management major in higher vocational colleges are basic service posts such as receptionists, waiters and tour guides. In the course construction, we should not only consider the employment of students, but also the future career development of students. In the construction of curriculum system, we should integrate theory with practice, lay equal stress on ability and quality and let students’ life become rich and colorful.

B. Based on the OBE theory, the process of designing the training plan for tourism management professionals is shown in Fig. 2.

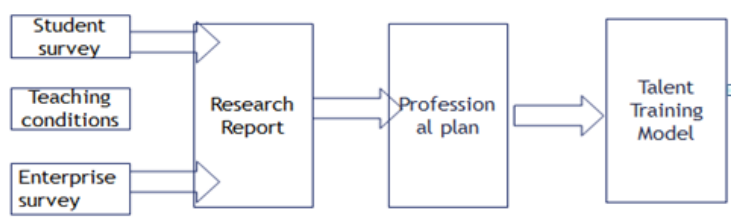

Fig. 2 Guiding ideas of professional construction

Based on the OBE theory, our final talent training program is based on full market research. We should not only investigate students and enterprises but also consider the teaching conditions of schools themselves. On the premise of full investigation, we should decompose professional competence and establish the curriculum system.

\section{Segmentation of Training Objectives For PROFESSIONAL TALENTS BASED ON OBE THEORY}

\section{A. Setting training objectives: what can students do after graduation}

The training objective is a description of the professional achievements of tourism management major in higher vocational colleges after three years of study. When formulating training objectives, we must fully consider all aspects of needs and conditions, such as school positioning, professional characteristics, social needs and parents' expectations. Training objectives should focus on reflecting what students can do after graduation, their professional fields, characteristics and abilities after graduation.

For example, Jiangsu Vocational College of Business aims to train high-quality technical and skilled personnel to meet the needs of tourism development and local economic construction in China. The personnel should have a strong sense of social responsibility, clear career ideal and good professional ethics, scientific and cultural qualities suitable for the professional field, solid tourism management professional knowledge, skilled tourism professional skills and comprehensive professional ability. They are competent for the service and management of modern travel agencies, star hotels, tourist attractions and tourism administrative departments.

\section{B. Decomposition of teaching requirements indicators: what can we embody}

We will further refine the graduation requirements into knowledge objectives, competence indicators and quality objectives. 


\section{1) Knowledge objectives}

Have the necessary professional knowledge of tourism;

Master the corresponding etiquette knowledge.

Grasp the basic situation of tourism and customs of the foreign countries;

Master the basic knowledge and analysis methods of tourism marketing;

Proficiency in basic knowledge, operation process and management knowledge of various departments of modern hotels;

Master the related knowledge of tour guide service and the basic knowledge, operation process and management knowledge of various departments of the travel agency.

\section{2) Capacity objectives}

Strong service and management capabilities of foreignrelated hotels, such as anteroom, guest room, catering, etc.

Strong tour guide skills and basic travel agency management and management capabilities;

Good tour guide ability in both Chinese and English and practical writing ability;

Have the humanistic qualities and professional endurance required by the professional development;

Skilled in using computers and typing in English;

Have a certain ability of public relations sales;

Have the ability of information collection and processing, communication and cooperation, problem-solving, organization and coordination, and lifelong learning.

Have certain innovation and entrepreneurship ability.

\section{3) Quality objectives}

Good political and ideological qualities, moral qualities and legal consciousness;

Have humanistic literacy, solid professional knowledge and good attitude towards life;

Have an honest, trustworthy, hardworking, positive and enterprising attitude towards work;

Good interpersonal skills, team spirit and customer service awareness;

Ability to strictly abide by post-operation norms;

Have a correct view of employment and entrepreneurial awareness;

Have the spirit of innovation and exploration.

\section{ESTABLISHING THE CORRESPONDING RELATIONSHIP BETWEEN CURRICULUM AND TRAINING OBJECTIVES}

According to OBE education theory, all teaching links and contents are organized around clear training objectives. We should really realize the student-centered curriculum system. We should have a clear mapping relationship between the indicators of graduation goals and curriculum structure. Every kind of ability is supported by a clear curriculum setting. Through the corresponding relationship, we can eliminate some repetitive courses and eliminate the courses that can not support the target points, and offer courses with professional characteristics. We should make the curriculum system fully able to support personnel training objectives and graduation requirements indicators. With such a matrix correspondence, both teachers and students can clearly identify the role of the courses offered in the process of students' training. [3]

TABLE I. ThE FrameWORK OF TOURISM MANAGEMENT COURSE SySTEM

\begin{tabular}{|c|c|c|c|}
\hline & & Job Capability Description & Subjects \\
\hline \multirow{11}{*}{$\begin{array}{l}\text { Professional Ability of } \\
\text { Tourism Management }\end{array}$} & \multirow{6}{*}{$\begin{array}{l}\text { Basic } \\
\text { Professional } \\
\text { Qualities }\end{array}$} & Professional Ethics & $\begin{array}{l}\text { 1. National Defense Education } \\
\text { 2. Ideological and Moral Cultivation and Legal Basis } \\
\text { 3. Mental Health } \\
\text { 4. Situation and Policy }\end{array}$ \\
\hline & & Physical Quality & 5.PE \\
\hline & & Mathematical Ability & 6.Advanced Mathematics \\
\hline & & Career Development Ability & 7.Career Development and Employment Entrepreneurship Guidance \\
\hline & & Verbal Skil & $\begin{array}{l}\text { 8.College English } \\
\text { 9. College Chinese }\end{array}$ \\
\hline & & Computer Skills & 10. Computer Application Foundation \\
\hline & \multirow{3}{*}{$\begin{array}{l}\text { Basic vocational } \\
\text { skill }\end{array}$} & Tourism Cognitive Ability & $\begin{array}{l}\text { 11. Introduction to Tourism } \\
\text { 12. Tourism Geography } \\
\text { 13. Tourism Literature }\end{array}$ \\
\hline & & Mathematical Ability & 14.Management \\
\hline & & $\begin{array}{l}\text { Tourism English } \\
\text { Communication }\end{array}$ & 15.Tourism English \\
\hline & \multirow[t]{2}{*}{$\begin{array}{l}\text { Career Core } \\
\text { Competence }\end{array}$} & Tour Guide's Ability & $\begin{array}{l}\text { 16. Basic Knowledge of Tour Guides } \\
\text { 17. Tourism Laws and Regulations } \\
\text { 18. Tour Guide Service Skills } \\
\text { 19. Overview of the Foreign Countries } \\
\text { 20. Tourism Aesthetics } \\
\text { 21. Tourism Psychology } \\
\text { 22. Tourism Etiquette }\end{array}$ \\
\hline & & $\begin{array}{c}\text { Operational Ability of } \\
\text { Travel Agency and Hotels }\end{array}$ & $\begin{array}{l}\text { 23. Tourism Marketing } \\
\text { 24. Operation and Management of Travel Agencies } \\
\text { 25. Hotel Service and Management 26. Tourism planning } \\
\text { 27. Human Resource Management in Tourism Enterprises } \\
\text { 28. Post Practice }\end{array}$ \\
\hline
\end{tabular}




\section{TEACHING EVALUATION}

In traditional professional teaching, we emphasize the systematicness of curriculum knowledge and the integrity of curriculum content. Sometimes we lack perfect assessment mechanism and scientific evaluation method. As teachers, we generally pass the usual results, and pay attention to the comprehensive score of mid-term examination results and final examination results. In the case of large class teaching, it is difficult to objectively assess each student's academic performance in a certain way of evaluation. This often results in students 'learning orientation of reciting textbooks and reexamining and the disconnection between students' classroom learning and social needs.

Based on the concept of OBE, we adopt this teaching evaluation system in the teaching of tourism management specialty, namely the feedback mechanism of "teachingevaluation-improvement of teaching-reappraisal". Teachers in the teaching process not only pay attention to students' academic performance and problems, but also to the effect of students' learning. Teachers often make a periodic evaluation in teaching. In this way, we can improve the teaching methods in time. Through teacher evaluation, student self-evaluation, group mutual evaluation, peer evaluation, employer evaluation and other evaluation methods, teachers promote students' reflection ability and encourage students to learn more actively. Ultimately, we can evaluate students' learning achievement scientifically and reasonably by synthesizing all kinds of evaluation opinions.

\section{CONCLUSION}

According to the strategy of national higher vocational talents training, we should consider the demand of tourism management industry and micro-enterprises for tourism-related talents training, and formulate a talent training program on the basis of the actual investigation. We should strengthen the guiding role of industry in teaching which is an effective way to design and improve the suitability of school personnel training and social needs. We should introduce OBE education concept into vocational education and establish the educational concept of "student-centered" and "achievement-oriented". We should construct the curriculum system of tourism management specialty in higher vocational colleges. In this way, students can not only systematically master professional theoretical knowledge and vocational skills, but also have the ability to deal with problems. Only in this way can we cultivate highquality skilled talents in line with market demand.

\section{REFERENCES}

[1] Gu Peihua, Hu Wenlong, Lin Pengbao, Lu Xiaohua, Xiong Guangjing and Chen Yan: Engineering Education Model Based on Learning Output OBE--Practice and Exploration of Shantou University. Research on Higher Engineering Education,2014 (01):28-37

[2] Cheng Chao, Liu Shiqiong, Liu Hongqi, Zhao Jun: Revision of Talents Training Scheme Based on OBE Concept - Taking Exploration Technology and Engineering Specialty of Southwest Petroleum University as an Example. Chinese Geological Education,2016 (01):4144

[3] Wu Qiufeng, Li Hongxia, Shen Yang: Research on Teaching Reform of Higher Engineering Specialty Based on OBE Perspective. Education Exploration E, 2016 (05):97-100 